\title{
シリコーンゴムボールを用いた 面駆動型ソフトアクチュエータの開発
}

\author{
則 次 俊 郎*1 井上 隆 志*2 佐々木 大 輔*1
}

\section{Development of Planar Type Soft Actuator using Silicone Rubber Balls}

\author{
Toshiro Noritsugu*1, Takashi Inoue ${ }^{* 2}$ and Daisuke Sasaki*1
}

\begin{abstract}
Recently, robots have been expected to be used in various fields such as not only usual manufacturing industry but also medical welfare, agriculture, security system and so on. Especially, in the coming advanced aged society, the demand of robot will be more increased in medical welfare and human assist technology. In such a field, since robots must work together with human or contact with a human body directly, they are required safety and flexibility.

In this study, in order to realize a flexible mechanisms satisfying the above requirements, a soft actuator has been developed. It is composed of a body made of silicone rubber and driven with a pneumatic power. Both the elasticity of rubber material and the air compressibility are effective to realize such a soft actuator. The developed planar type soft actuator has two layer structure built up with silicone rubber hemispheres and balls, which may be available to carry fragile and shapeless objects, furthermore, to execute flexible contacting tasks for human body. This paper describes a principle of operation, a control method and a fundamental control performance of the proposed actuator.
\end{abstract}

Key Words: Soft Actuator, Pneumatics, Robot, Silicone Rubber, Soft Mechanics

\section{1. 緒言}

近年，生産現場だけでなく様々な分野でロボットが利用され ている．特に医療現場や家庭内において人間を対象とした作業 を行うロボットなど，柔軟で傷付きやすい対象物を扱うロボッ トや機械システムの開発に関心が高まっている [1] [2].このよう なシステムには作業対象物に対する優しさと安全性が第一に求 められ，これらの要求を満足するための一つの手段はロボット や機械システムのメカニズム自体が柔軟性を有するいわゆるソ フトメカニズムを構成することである。本研究では，このよう なソフトメカニズムを構成するためのアクチュエータに注目し， 本質的に柔軟なゴム材料と空気压駆動を組み合わせた新しい空 気圧アクチュエータを提案する。一般に, 空気圧アクチュエー 夕は, 出力／重量比が高く, 小型・軽量化が容易であり, さら に空気の圧縮性による高いコンプライアンスにより, 柔軟性が 必要な場面での活用が期待される [3].

ゴムを素材とし空気圧で駆動されるいくつかの形式のソフト アクチュエータが提案されている [4]. 本研究では, 柔軟な搬送 機構の開発を目的として平面 2 自由度ソフトアクチュエータ（以

原稿受付 2000 年 11 月 27 日

${ }^{* 1}$ 岡山大学工学部

$* 2$ (株) 鳥津製作所

${ }^{* 1}$ Faculty of Engineering, Okayama University

${ }^{* 2}$ Shimadzu Corporation
下，面駆動型ソフトアクチュエータと呼ぶ）を開発する。この 種のアクチュエータとして,ゴムチューブを上下 2 層に並べた 弾性平面体による蠕動方式 [5], 内部に複数の圧力室を有する薄 板とフィンを利用した進行波駆動方式 [6], バルーンによる反り 上げ方式 [7] などの搬送用アクチュエータが提案されている.こ れらのアクチュエータでは直線 1 自由度の運動のみが可能であ り, 平面 2 自由度の運動を行うためには 2 組のアクチュエータ を組み合わせる必要がある。これに対して, 筆者らは, ゴムボー ルを用いた独自の構造を用いることにより，平面内の任意方向 への搬送運動が可能なアクチュエー夕を開発している. 前報 [8] では，ソフトテニスボールを用いた大型のアクチュエータを試 作し，基本的な動作原理を説明した。本論文では，金型を用い たシリコーンゴムの一体成形による小型アクチュエータを試作 し, 二次元平面内の 2 自由度の搬送性能を考察する.

本研究で提案する面駆動型ソフトアクチュエータは, シリコー ンゴムボールからなる多数の基本ユニットを平面上に配置した ものである.ゴムボールの内圧制御により，それぞれのボール の膨張と収縮の夕イミングを調整することにより二次元平面内 の任意方向への進行波を発生させ，これによりボール上に置か れた対象物を任意方向に搬送できる。アクチュエー夕本体が柔 軟であるため，壊れやすい対象物や不定形状の対象物など広範 な応用分野が期待される。本論文では，まず，アクチュエー夕 の構造と動作原理を説明した後, 所望の進行波を発生させるた めの圧力制御について記述する。次に，いくつかの実験結果に 


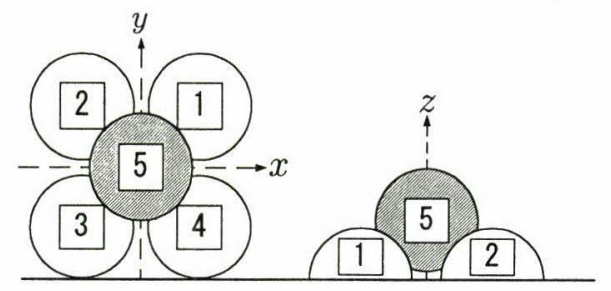

Fig. 1 Fundamental construction

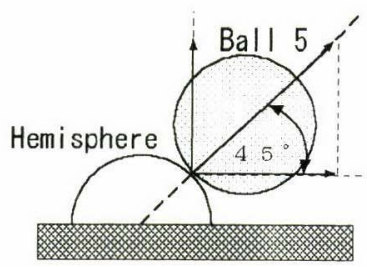

Fig. 2 Angle of $45^{\circ}$

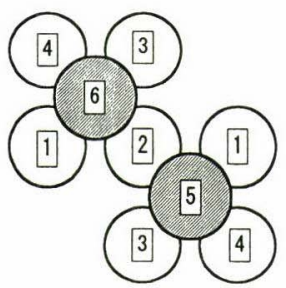

Fig. 3 A planar type soft actuator composed of 9 balls

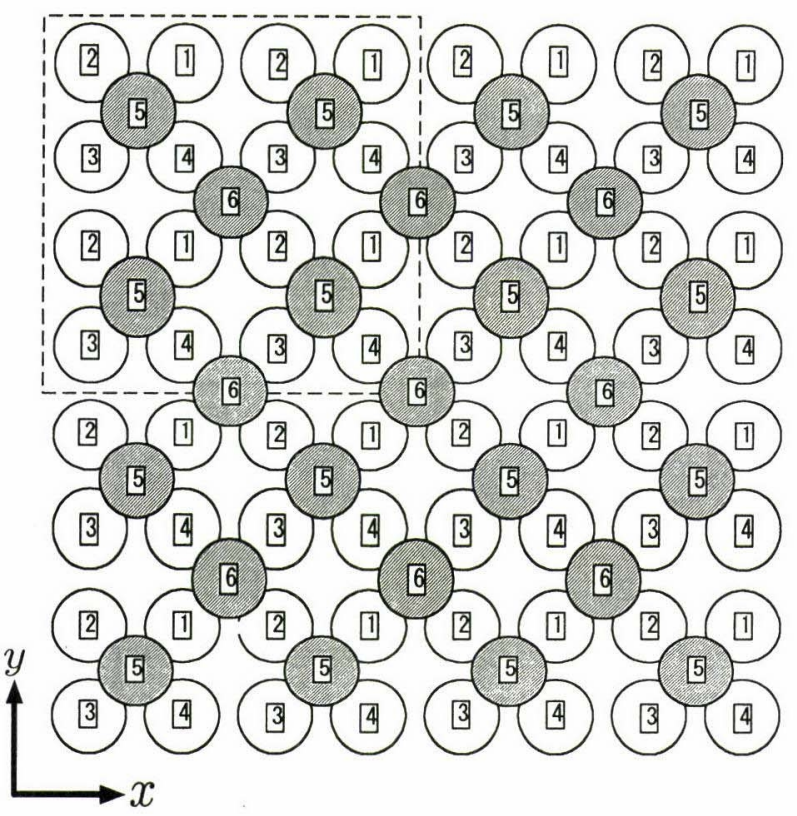

Fig. 4 Planar type soft actuator composed of 89 balls 基づいて，提案するアクチュエータの有効性を示す.

\section{2. アクチュエータの構造}

Fig. 1 にアクチュエータを構成する基本ユニットの構造を示 す.このユニットは 4 個の半球状ゴムボール上に 1 個のゴムボー ルを配置し, 上段のボール 5 が物体と接触することにより搬送 動作を行い, 下段の半球状ゴムボール $1,2 ， 3 ４$ は搬送方向 と搬送速度を決定する. Fig. 2 に示すように，上段のボール 5

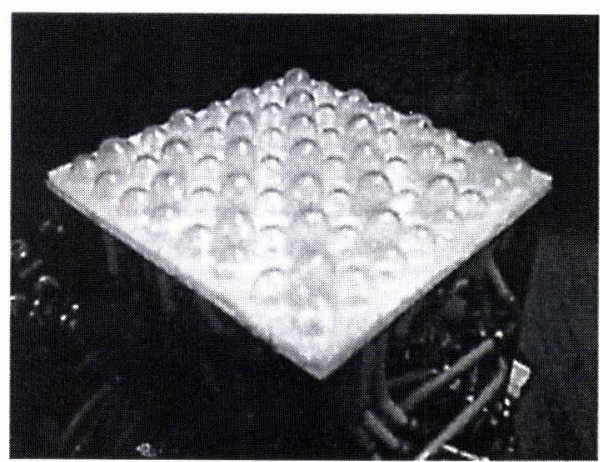

Fig. 5 Planar type soft actuator

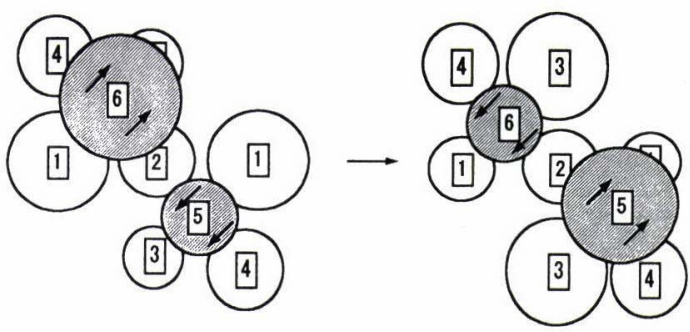

Fig. 6 Operation of other direction

は下段の 4 個の半球状ゴムボール上に $45^{\circ}$ の角度で固定してい る。また，ボール間に空気の行き来はなく，それぞれの内圧は 独立に制御される。

Fig. 3 に示すように基本ユニットを点対称に配置することに

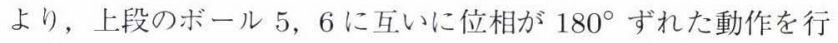
わせる。

Fig. 3 のユニットを多数組み合わせることにより, Fig. 4 に 示すような面駆動型アクチュエータが構成できる. Fig. 5 に試 作した面駆動型ソフトアクチュエータを示す. 搬送対象物は上 段ボール 5,6 の上に設置される。同じ番号のボールは同一の 圧力により制御されるため, 理論的にはボールの総数にかかわ らず 6 個の制御并によりアクチユエータの駆動が可能である.

\section{3. 動 作 原 理}

\section{1 基本動作}

Fig. 6 にアクチュエータを斜め方向（45 度方向）へ動作さ せる場合の状態を示す. Fig. 3 の状態から, 半球状ボール 2,4 の内压を平衡圧力 $\left(P_{\text {ave }}\right)$ とし, 半球状ボール 1 の内压を上げ

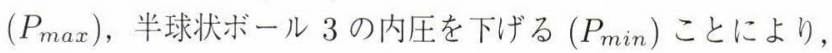
上段ボール 5,6 はそれぞれ半球状ボール 3 の方向へ押される. 次に半球状ボール 1,3 の内圧を反転させることによりボール 5,6 は半球状ボール 1 の方向へ押される。このように, 半球状

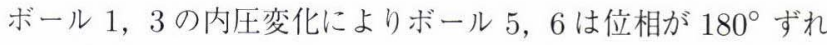
た運動を行い，ボール $1 ， 3$ の内圧を周期的に切り換えること により，上段ボール 5,6 は Fig. 6 の矢印の方向に摇動運動を 行う.

ここで，所定の搬送方向へ動作する上段ボールは内圧を上げ て膨張させ，反対方向へ動作する上段ボールは内圧を下げて収 縮させる。これにより，搬送方向へ運動しているボールと搬送物 


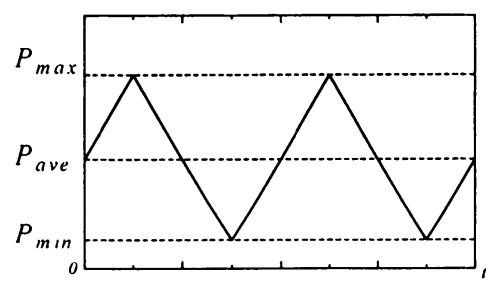

Fig. 7 Reference path of pressure

(a)

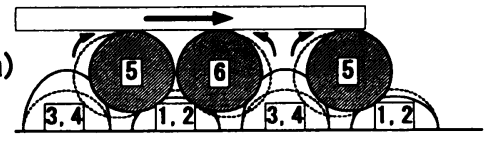

(b)

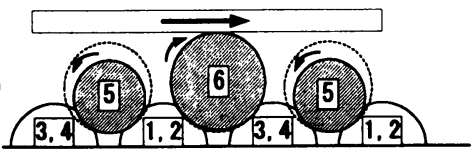

(c)

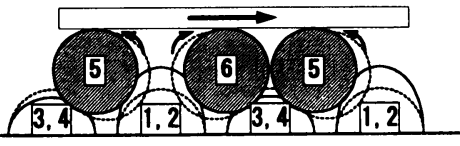

(d)

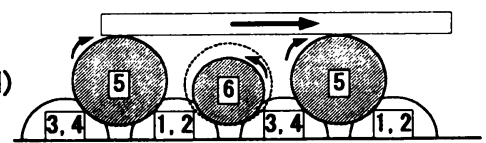

Fig. 8 Operation of planar type soft actuator

が接触することになり，搬送物を望む方向に移動させることが できる。それぞれのボールの内圧は，Fig. 7 に示す三角波形の 目標圧力パターンにより制䘖する。 $P_{a v e}$ は平衡压力, $P_{\text {max }}$ お よび $P_{\text {min }}$ は最大圧力と最小压力である。このような目標压力 パターンがアクチュエータの動作の基本であり, 二次元平面内 で対象物を搬送するための目標压力を決定する方法は後述する.

\section{2 搬送動作の具体例}

アクチュエータの $y$ 軸方向の運動について考える.この場合, 上段のボールは $x$ 軸方向へは動作しないため, $y$ 軸方向に対 称に配置された半球状ボール 1 と 2 , 半球状ボール 3 と 4 は, それぞ柌じ内圧変化となる。このため面駆動型アクチュエー 夕を真横 $(x$ 軸正側 $)$ から見た四はFig. 8 のようになる.点 線は平衡圧力 $P_{\text {ave }}$ におけるボールの大きさを表す. 図中上段 ボールに付けられた矢印はボールの運動方向を表す。上段ボー ルと対象物間にすべりがなければ，上段ボールの摇動運動の左 右方向成分が 1 周期当たりの搬送距離に相当する. 対象物は上 段ボールの上下方向成分により多少の上下運動をしながら搬送 方向に進行する. Fig. 9 に, $y$ 軸方向へ搬送運動をさせる場合 の下段半球状ボールと上段ボール内圧の目標圧力パターンを示 す. Fig. 9(a)において, 点線は半球状ボール 1, 2, 実線は半 球状ボール 3,4 の圧力を示し, Fig. 9(b) では点線がボール 5, 実線がボール 6 の圧力を示す.

搬送動作の過程は以下のように説明される。

(a) ボール 1, 2 の内压は $P_{\min }$, ボール 3, 4 の内圧は $P_{\text {max }}$ であり, ボール 5,6 はボール 1,2 側へ寄った状態である. ボール 5,6 の内压は P ave であり, 搬送物は上段ボール 5 ,

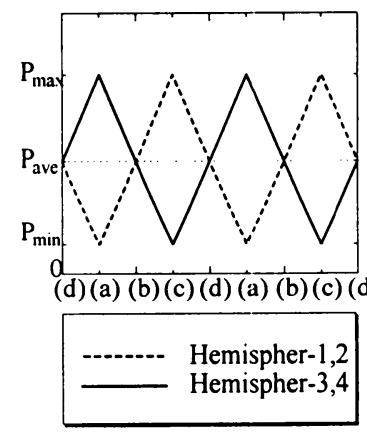

(a)

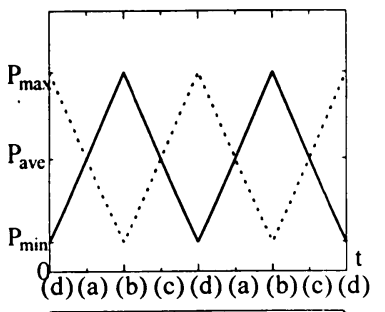

Ball-5 Ball-6
Fig. 9 Reference path of pressure

6 の両方に接触している.ここで, ボール 5 からボール 6 への搬送物の受け渡しが行われる. (d) から (a) の過程で は, ボール 5 は収縮, ボール 6 は膨張しながら, 搬送物は $y$ 軸の正の方向（右方向）へ移動する

(b) ボール $1,2,3,4$ の内圧は $P_{a v e}$, ボール 5 の内圧は $P_{\text {min }}$, ボール 6 の内圧は $P_{\text {max }}$ である. (a) から (b) の過程では, ボール 5 は収縮, ボール 6 は膨張することにより, 搬送物 はボール 6 に接触して右方向へ移動する.

(c) ボール 1, 2 の内圧は $P_{\max }$, ボール 3,4 の内圧は $P_{\text {min }}$ であり,ボール 5,6 はボール 3,4 側へ寄った状態である. ボール 5,6 の内压は $P_{a v e}$ であり，搬送物は上段ボール 5 , 6 の両方に接触している。ここで, ボール 6 からボール 5 への搬送物の受け渡しが行われる. (b) から (c) の過程で は, ボール 5 は膨張, ボール 6 は収縮しながら, 搬送物は 右方向へ移動する.

(d) ボール 1, 2, 3, 4の内压は $P_{\text {ave }}$, ボール 5 の内压は $P_{\max }$, ボール 6 の内压は $P_{\min }$ である. (c) から (d) の過程では, ボール 5 は膨猆，ボール 6 は収縮することにより，搬送物 はボール 5 に接触して右方向へ移動する.

以上の一連の動作 $(\mathrm{a}) \rightarrow(\mathrm{b}) \rightarrow(\mathrm{c}) \rightarrow(\mathrm{d}) \rightarrow(\mathrm{a})$ を繰り返すこと により。面駆動型アクチュエータ上に置かれた対象物を $y$ 軸方 向 (右方向) へ搬送できる.

\section{4. 圧力制御 系}

目標圧力の設定法について記述する。提案したアクチュエー 夕の機構にはボールの変形やボール間の干渉などかなり複雑な 問題が含まれるため現時点では厳密な解析は容易でない．そこ で，压力制御アルゴリズムの導出にあたり，次の仮定を設ける。 仮定 1）下段ボールと上段ボールの接触角度は, すべてのボー ルで等しくかつ一定である。

仮定 2) アクチュコータを構成するすべてのボールの剛性を表 す係数は等しい.

仮定 3）アクチュコータの $x, y, z$ 軸方向の剛性を表す係数は 等しい.

仮定 4) アクチュエータの動特性は無視できる.

ボールの内圧が平衡圧力 $P_{\text {ave }}$ から $\delta P_{j}$ だけ変化したとき, ボールの半径の変化量 $\delta R_{j}$ は次式により表されるとする. 


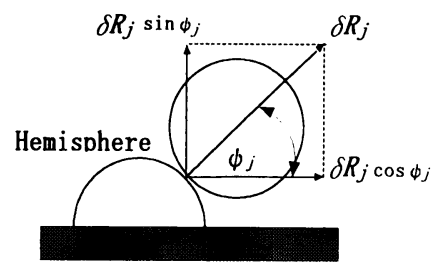

Fig. 10 Angle of $\phi$ j

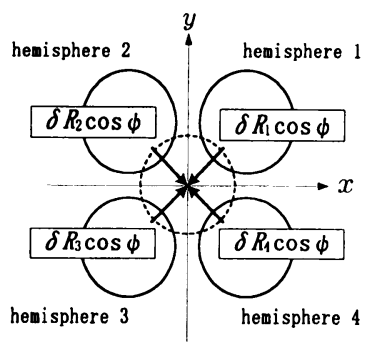

Fig. 11 Compornent of horizontal direction

$$
\delta R_{j}=\frac{\delta P_{j}}{k_{j}}
$$

ここで， $k_{j}$ はボールの剛性を表す係数であり，添字 $j(j=1,2$, 3，4)は下段の各半球状ボールに対応する。

Fig. 10 に上段ボールと下段ボールの接続の様子を示す。下 段ボールと上段ボールの接触角度を $\psi_{j}$ とすると, 下段ボール の半径変化量 $\delta R_{j}$ は水平方向の成分 $\delta R_{j} \cos \psi_{j}$ と鉛直方向 の成分 $\delta R_{j} \sin \psi_{j}$ に分解される.さらに, Fig. 11 に示すボー ルの配置関係に基づいて, $\delta R_{j} \cos \psi_{j}$ を各軸方向に分解し，そ れぞれを合成することにより次式が求められる。仮定 1）より, $\psi_{1}=\psi_{2}=\psi_{3}=\psi_{4}=\psi$ とする.

$$
\begin{aligned}
\delta x & =\frac{\sqrt{2}}{2} \cos \psi\left(-\delta R_{1}+\delta R_{2}+\delta R_{3}-\delta R_{4}\right) \\
\delta y & =\frac{\sqrt{2}}{2} \cos \psi\left(-\delta R_{1}-\delta R_{2}+\delta R_{3}+\delta R_{4}\right) \\
\delta z & =\sin \psi\left(\delta R_{1}+\delta R_{2}+\delta R_{3}+\delta R_{4}\right)
\end{aligned}
$$

ここで, $\delta x, \delta y, \delta z$ は, 下段ボールの半径変化によって生じる 上段ボール中心点の $x, y, z$ 軸方向への移動量を表す。次に, $x, y, z$ 軸方向の剛性を表す係数を $k_{x}, k_{y}, k_{z}$ とし, 次式の ような各軸方向の仮想圧力 $\delta P_{x}, \delta P_{y}, \delta P_{z}$ を定義する.

$$
\begin{aligned}
& \delta P_{x}=k_{x} \delta x \\
& \delta P_{y}=k_{y} \delta y \\
& \delta P_{z}=k_{z} \delta z
\end{aligned}
$$

これらの仮想圧力は, 上段ボールを $\delta x, \delta y, \delta z$ だけ移動させ るために必要な各軸方向の等価的な圧力変化を表す．仮定 2）上 り $k_{1}=k_{2}=k_{3}=k_{4}=k_{b}$, 仮定 3) より $k_{x}=k_{y}=k_{z}=k_{a}$ と置く.このとき式 $(5) \sim(7)$ に, 式 (1)～(4) を代入するこ とにより次式が求められる.

$$
\begin{aligned}
& \delta P_{x}=\frac{\sqrt{2} k_{a}}{2 k_{b}} \cos \psi\left(-\delta P_{1}+\delta P_{2}+\delta P_{3}-\delta P_{4}\right) \\
& \delta P_{y}=\frac{\sqrt{2} k_{a}}{2 k_{b}} \cos \psi\left(-\delta P_{1}-\delta P_{2}+\delta P_{3}+\delta P_{4}\right)
\end{aligned}
$$

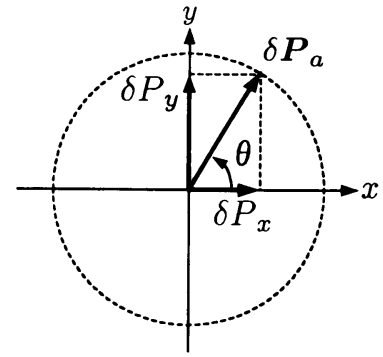

Fig. 12 Angle of $\theta$

$$
\delta P_{z}=\frac{k_{a}}{k_{b}} \sin \psi\left(\delta P_{1}+\delta P_{2}+\delta P_{3}+\delta P_{4}\right)
$$

上段ボールは，これらの仮想圧力 $\delta P_{x}, \delta P_{y}, \delta P_{z}$ の合成ベクト ルの方向と大きさに基づいて運動すると考えることができる.

下段の半球状ボール $1,2,3,4$ の内圧変化ベクトルを $\delta \boldsymbol{P}=$ $\left[\delta P_{1}, \delta P_{2}, \delta P_{3}, \delta P_{4}\right]^{T}$, 各軸方向の仮想圧力ベクトルを $\delta \boldsymbol{P}_{r}=$ $\left[\delta P_{x}, \delta P_{y}, \delta P_{z}\right]^{T}$ とすると, $\delta \boldsymbol{P}$ と $\delta \boldsymbol{P}_{r}$ の関係は次式で表さ れる。

$$
\delta \boldsymbol{P}_{r}=\frac{k_{a}}{k_{b}} \boldsymbol{N}_{0} \delta \boldsymbol{P}
$$

$N_{0}$ は次式で与えられる.

$$
\boldsymbol{N}_{0}=\left[\begin{array}{cccc}
-\frac{\sqrt{2}}{2} \cos \psi & \frac{\sqrt{2}}{2} \cos \psi & \frac{\sqrt{2}}{2} \cos \psi & -\frac{\sqrt{2}}{2} \cos \psi \\
-\frac{\sqrt{2}}{2} \cos \psi & -\frac{\sqrt{2}}{2} \cos \psi & \frac{\sqrt{2}}{2} \cos \psi & \frac{\sqrt{2}}{2} \cos \psi \\
\sin \psi & \sin \psi & \sin \psi & \sin \psi
\end{array}\right]
$$

各ボールの内压は Fig. 9 に示す三角波の夕イミングに基づい て制御する。そこで，それぞれの三角波の圧力振幅が決まれば 各ボール内圧の目標値を記述することができる，以下では，上 記のモデル化に基づいて圧力振幅の計算法を示す.

基本ユニット内で対角線上に配置されたボール 1 と 3 および

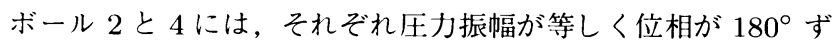
れた内圧変化を行わせるものとし, 次式のような制約条件を与 える。

$$
\begin{aligned}
& \delta P_{1 \max }+\delta P_{3 \max }=0 \\
& \delta P_{2 \max }+\delta P_{4 \max }=0
\end{aligned}
$$

また, $z$ 軸方向の発生力は $x, y$ 軸方向の搬送運動に影響を及ほ さないため, ここでは, $x, y$ 軸方向のみの仮想圧力を考慮すれ ば，下段半球状ボールの圧力振幅 $\delta \boldsymbol{P}_{m}=\left[\delta P_{1 \text { max }}, \delta P_{2 \max }\right]^{T}$ は仮想圧力 $\delta \boldsymbol{P}_{a}=\left[\delta P_{x}, \delta P_{y}\right]^{T}$ を用いて次式により与えられる。

$$
\delta \boldsymbol{P}_{m}=\frac{k_{b}}{k_{a}} \boldsymbol{N}^{-1} \delta \boldsymbol{P}_{a}
$$

$N$ は次式で与えられる

$$
\boldsymbol{N}=\left[\begin{array}{cc}
-\sqrt{2} \cos \psi & \sqrt{2} \cos \psi \\
-\sqrt{2} \cos \psi & -\sqrt{2} \cos \psi
\end{array}\right]
$$

対象物を指定した方向入搬送させるためには，上段ボール 5,6 を指定した方向へ摇動運動させる必要がある，そこで，Fig. 12 


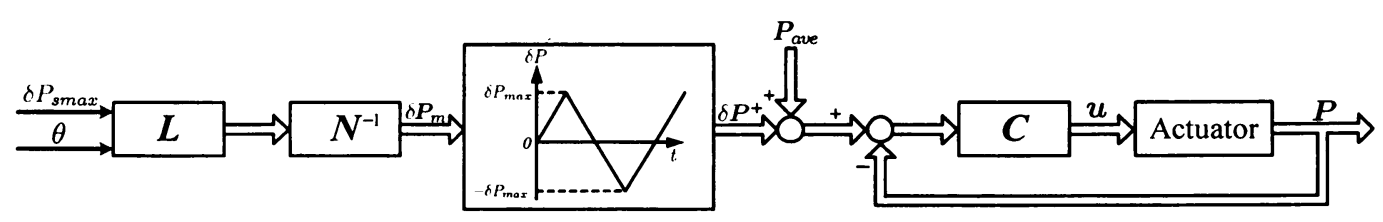

Fig. 13 Pressure control system

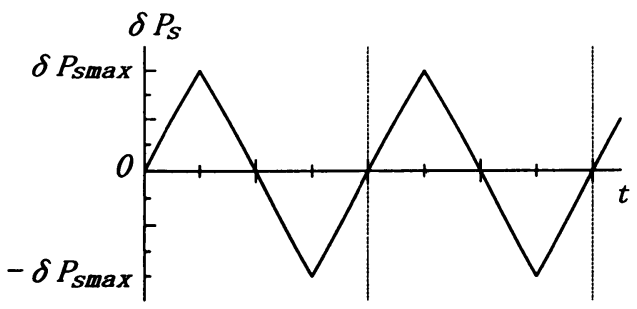

Fig. 14 Reference path of pressure

に示すように仮想圧力ベクトル $\delta \boldsymbol{P}_{a}$ が $x$ 軸の正方向となす角 を $\theta$ とおき, $\delta \boldsymbol{P}_{a}$ の大きさ $\delta P_{a \max }$ により搬送ストロークの 大きさ, 角度 $\theta$ により搬送方向を与えるものとする． $\delta \boldsymbol{P}_{a}$ と $\delta P_{\text {amax }}$ および $\theta$ の関係は次式により表される.

$$
\delta \boldsymbol{P}_{a}=\delta P_{a \max } \boldsymbol{L}
$$

$\boldsymbol{L}$ は次式により与えられる。

$$
\boldsymbol{L}=\left[\begin{array}{l}
\cos \theta \\
\sin \theta
\end{array}\right]
$$

ここで，簡単のため， $\delta P_{\text {smax }}$ を次式により定義する.

$$
\delta P_{\text {smax }}=\frac{k_{b}}{k_{a}} \delta P_{\text {amax }}
$$

このとき, 式（15）（18）より压力制御アルゴリズムは Fig. 13 のように表現できる。 $\delta P_{\text {smax }}$ および $\theta$ を独立変数として与え ることにより，未知定数 $k_{a} ， k_{b}$ を用いることなく下段ボールの 圧力振幅 $\delta \boldsymbol{P}_{m}$ を求めることができる．さらに，式 (13),(14) を考慮すれば，各下段ボールの三角波内圧変化の目標值を求め ることができる．Fig. 13 は圧力制御系の構成を示し， $\boldsymbol{P}_{\text {ave }}$ は 平衡圧力, $\boldsymbol{P}$ は圧力七ンサの出力, $u$ は制御入力, $C$ はコン トローラである. Fig. 14 に示すような $\delta P_{\text {smax }}$ を振幅とする 圧力制御を行うことにより上段ボールの摇動運動が可能となり， この摇動運動に同期させて上段ボールの膨張・収縮を制御する ことによりアクチュエータ上に置かれた対象物を搬送できる。

すでに自明のように, 上段ボール 5,6 の収縮と膨張は, 摇動 運動を整流することにより搬送方向への進行波を生成するため に利用される。ボール 5,6 の収縮と膨張は, 厳密には下段ボー ルの運動に対する負荷となり，また，前述のように，対象物の 多少の上下運動を引き起こす，ボール 5, 6 の収縮と膨張はこの ような影響を及ほすが，アクチュエータの動作に対して本質的 な影響はないものと考える.

以下では圧力制御アルゴリズムの有効性を実験により検証す る.なお，Fig.13はアクチュエータを駆動するための圧力制御 系を記述したものである.アクチュエータの変位を最終出力と する制御系を構成するためには，何らかの変位センサを用いて

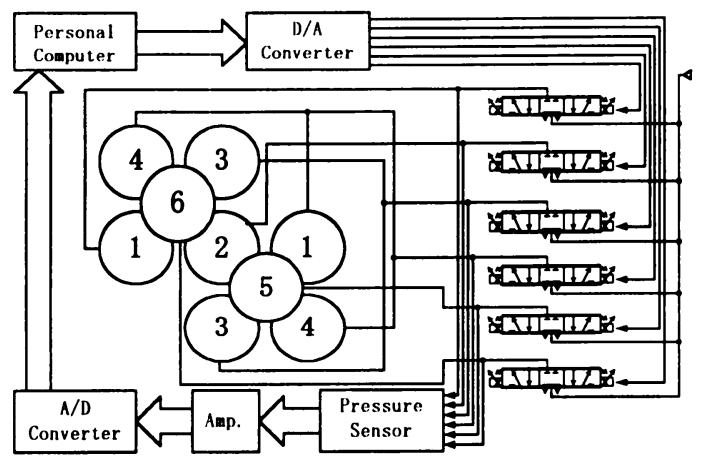

Fig. 15 Control system

Fig. 13 の圧力制御系を内蔵する位置の閉ループ制御系を構成 すればよい。この位置の閉ループ制御系の構成は今後の課題と する。

\section{5. 実験結果および考察}

Fig. 15 に実験装置を示す。実験に用いたゴムボールは，内 圧が大気圧の状態において外径 $12[\mathrm{~mm}]$, 肉厚 $1[\mathrm{~mm}]$ である. 以下では，すべてのゴムボールの平衡圧力を $P_{\text {ave }}=30[\mathrm{kPa}]$, 下段ボールと上段ボールの接触角を $\psi=45$ [deg.] に設定し， Fig. 13 に示した圧力制御系のコントローラ $C$ には PI 制御器 を用いる。制御器のゲインは試行錯誤によりチューニングした。

搬送動作時の上段ゴムボールの内圧は平衡圧力から振幅 $25[\mathrm{kPa}]$ の三角波により制御する.搬送対象物としてマークシー ルを付けた透明アクリル板を使用する．カメラによりマークシー ル中心の移動を測定し，これにより対象物の移動距離を求める. 透明アクリル板は縦横 $140[\mathrm{~mm}] \times 140[\mathrm{~mm}]$, 厚さ $2[\mathrm{~mm}]$, 質 量 41 [g]であり，アクチュエータとほほ同じ大きさである．実験 に用いたアクチュエータの最大搬送距離は $70[\mathrm{~mm}]$ 程度である。

\section{1 駆動周波数の搬送速度への影響}

種々の駆動周波数に対して対象物の搬送距離 $r$ を測定した 結果をFig. 16 に示す. $r$ は 20 秒間における搬送距離であ る. 入力圧力振幅は $\delta P_{\text {smax }}=30[\mathrm{kPa}]$ とし, 目標搬送方向 は $\theta_{r}=0$ [deg.], 30 [deg.], 45 [deg.], 60 [deg.], 90 [deg.] とし ている.

$\theta_{r}=0[\mathrm{deg}$.$] および 90[\mathrm{deg}$.$] は，それぞれ x$ 軸および $y$ 軸 方向への搬送に相当し，駆動周波数の増加に伴い搬送距離も増 加している，一方これらの軸方向以外への搬送においては，駆 動周波数 $1.0[\mathrm{~Hz}]$ 以上では搬送距離の増加が抑えられている. 4 章で示したように $\theta_{r}=0[\mathrm{deg}$.] および 90 [deg.] 以外の搬送方 向を実現するためには下段ボールにかなり微妙な圧力制御が要 求される. 駆動周波数が高くなるとボール内圧の応答遅れの影 響により圧力制御の精度が低下し，この結果，搬送性能の劣化 


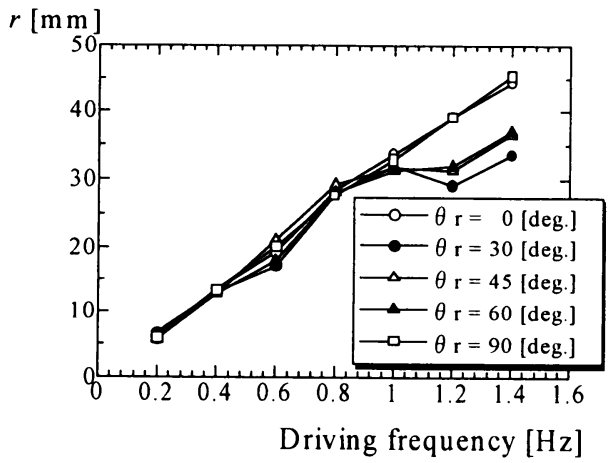

Fig. 16 Relation between driving frequency and carrier distance

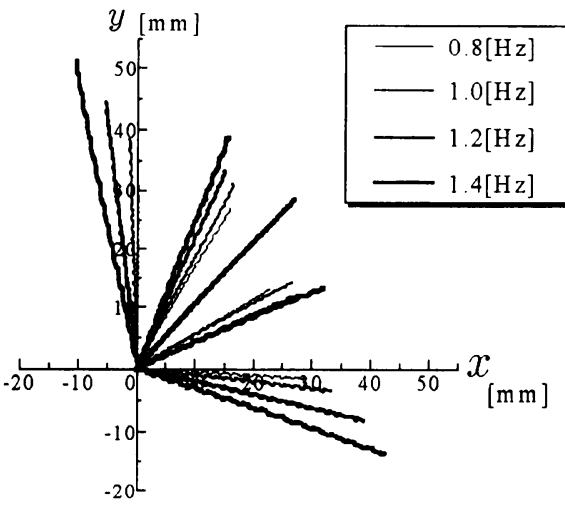

Fig. 17 Carring of $\theta$ direction

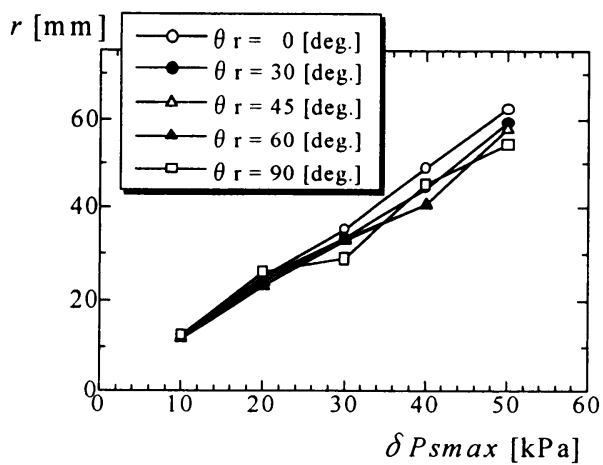

Fig. 18 Relation between $\delta$ Psmax and carrier distance

が生じたものと考えられる。また，Fig.17に対象物の移動の 軌跡を示す．駆動周波数が高くなるにつれて，移動方向と目標 方向とのずれが増加している。これらを考虑すれば, 本研究で 試作したアクチュエータの駆動周波数は, $1[\mathrm{~Hz}]$ 程度が妥当で あると考えられる。

\section{2 入力圧力振幅の搬送速度への影響}

入力圧力振幅 $\delta P_{\text {smax }}$ と搬送距離 $r$ の関係を測定した結果を Fig. 18 に示す. 入力圧力振幅が大きくなるほど下段ゴムボー ルの膨張 ·収縮の振幅も大きくなり, 上段ボールの摇動振幅が 増加する. 目標搬送方向は $\theta_{r}=0$ [deg.], 30 [deg.], 45 [deg.], 60 [deg.], 90 [deg.] とし，駆動周波数は $1.0[\mathrm{~Hz}$, $r$ は 20 秒間 における搬送距離である。

$\delta P_{\text {smax }}$ の増加により目標圧力（三角波）の勾配が大きくな

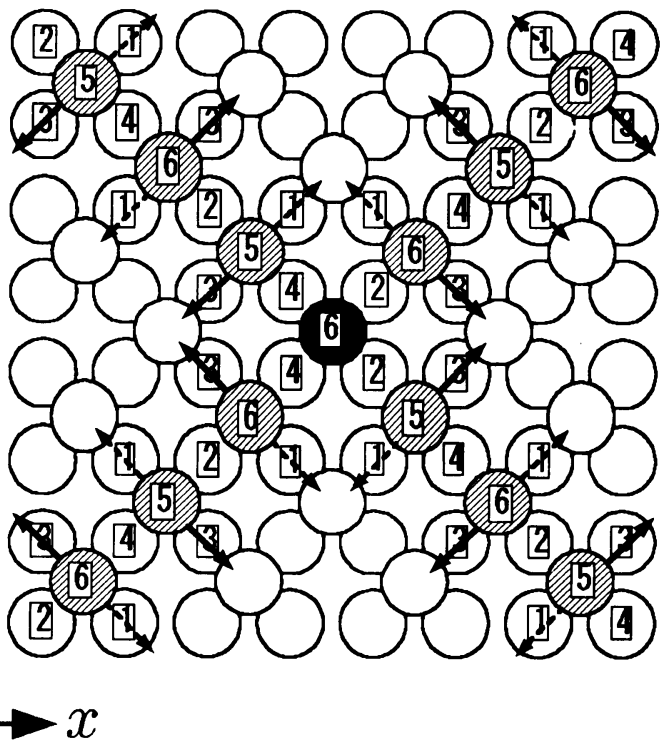

Fig. 19 Revolution of planar type soft actuator

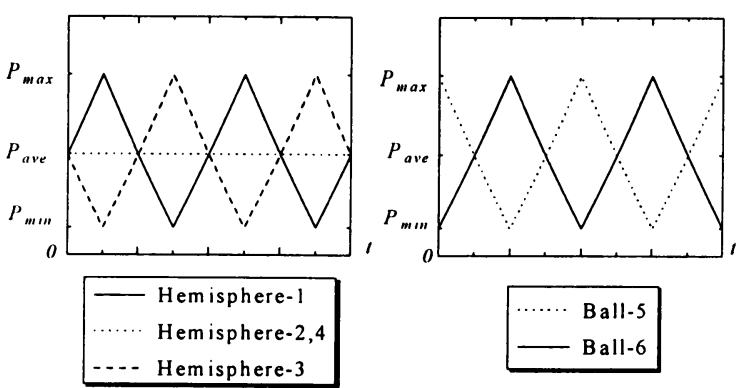

Fig. 20 Reference revolution of pressure

るため圧力応答遅れの影響が顕著になる．このため， $\delta P_{\text {smax }}$ が 大きくなると，搬送方向によるばらつきが若干大きくなる．な お，入力圧力は，ボールの保護を考慮して最大耐圧よりも低め に設定している。

以上の結果を考慮して, 以下の実験では，駆動周波数は $1.0[\mathrm{~Hz}]$, 入力圧力振幅は $\delta P_{\text {smax }}=40[\mathrm{kPa}]$ と設定する.

\section{3 回転運動}

一つの応用例として，搬送物を回転させた場合の結果を示す。

Fig. 19 は，アクチュエータの中心で対象物を回転運動させる ための基本ユニットの配置を示す. Fig. 20 にそれぞれのボー ルの目標压力パターンを示す。これは，アクチュエータの中心 から同心円上に位置する基本ユニットが，対角線と直角方向へ 駆動するように基本ユニット内の各半球状ゴムボールおよび上 段ゴムボールを配置したものである。下段の半球状ゴムボール 2,4 は平衡圧力に固定する。半球状ゴムボール 1 および 3 の膨 張と収縮により上段ゴムボール $5 ， 6$ は図中矢印のような摇動 運動を行う。対象物を反時計方向に回転させる場合には，上段 ゴムボール 5 が実線の矢印，上段ボール 6 が破線矢印の方向へ 摇動する場合にそれぞれを膨張させればよい，また，図中の番 号のないボールはすべて大気圧としている.

対象物の中心および中心から $40[\mathrm{~mm}]$ 離れた点の軌跡を Fig. 21 に示す. $\delta P_{\text {smax }}=40[\mathrm{kPa}]$, 駆動周波数 $1.0[\mathrm{~Hz}]$ と 


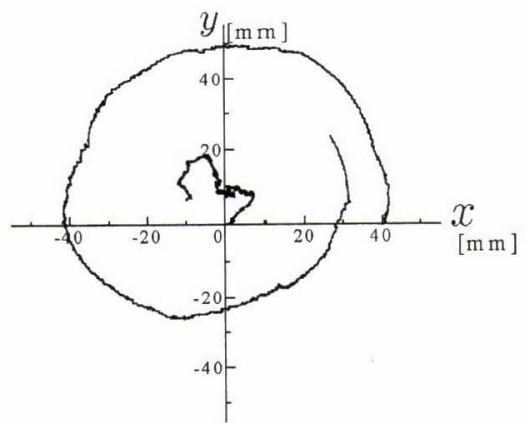

Fig. 21 Result revolution

し，170 秒間アクチュエータを駆動した。実験開始時の対象物 の中心を原点, 中心から $40[\mathrm{~mm}]$ 離れた点を $x$ 軸上にとって いる。二つの終点は，初期位置よりも多少ずれているが，アク チュエータ中心回りの回転動作が可能であることわかる.

\section{6. 結言}

本研究では，金型により成形したシリコーンゴムボールを用 いて, 上下 2 層構造の面駆動型ソフトアクチュエータを試作し た。アクチュエータの構造と動作原理, アクチュエータを駆動 するための圧力制御系について記述した後，実験により基本的 な動作性能を調べた。これにより，下記の結果を得た。

(1) 提案した圧力制御系は有効に機能し, 二次元平面内におい て目標とする任意方向への対象物の搬送が可能である。た たし，現時点では対象物の位置について開ループ制御を実 行しているため，ボール内圧の応答遅れなどに起因して搬 送方向に誤差が生じる。この誤差は，必要であればカメラ
などを用いて閉ループ制御系を構成することにより減少さ せることができる。

（2）本アクチュエータは, 理論的には駆動周波数および入力压 力振幅の増加により搬送速度が増加するが, ボール内压の 応答遅れやボールの耐压性能によってこれらのパラメータ は制約される。実用においては，用途に応じたゴムボール の弾性特性やサイズ, 制御弁の仕様などを決定する必要が ある。これらのアクチュエー夕設計の問題は今後の課題と している

最後に, 本研究は, 日本学術振興会未来開拓学術研究推進事業 の一環として実施されたことを付記し，関係者に謝意を表する．

\section{参 考 文 献}

[1]人間共存型ロボット専門委員会: “人間共存型ロボットシステムにおけ る技術課題”, 日本ロボット学会誌, vol.16, no.3, pp.288-294, 1998.

[2] 内山：“ソフトロボティクス”, 日本ロボット学会誌, vol.17, no.6, pp.756-757, 1999.

[3] 則次: “空気圧アクチュエータ”, 日本ロボット学会誌, vol.15, no.3, pp.355-359, 1997.

[4] 則次：“ソフトアクチュエータ”, 日本ロボット学会誌, vol.17, no.6, pp.795-798, 1999.

[5] 石川, 仕入: “多孔弾性平面体による蠕動アクチュエー夕の開発一蠕動 方式の提案および武作-”, 第 13 回日本ロボット学会学術講演会子稿 集, pp.329-330, 1995 .

[6] 鈴森：“進行波駆動形空圧ゴムアクチュエー夕の研究”, 日本機械学会 論文集 (C 編), vol.64, no.621, pp.1568-1573, 1998.

[7] 河合, P. Cusin, 小西：“バルーンアクチュエー夕を用いた搬送機構”, 第 17 回日本ロボット学会学術講演会予稿集, pp.955-956, 1999.

[8] T. Noritsugu, D. Kaneshiro and T. Inoue: "Soft Planar Actuator using Pneumatic-Rubber Balls," J. Robotics and Mechatronics, vol.12, no.3, pp.254-260, 2000.

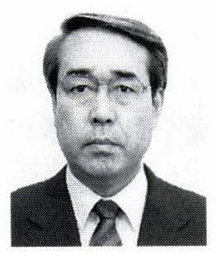

則次俊郎 (Toshiro Noritsugu)

1949 年 10 月 19 日生. 1974 年岡山大学大学院工学 研究科修士課程修了. 津山工業高等専門学校老経て, 1986 年岡山大学工学部助教授, 1991 年同大学機械 工学科教授, 1996 年同大学システム工学科教授, 現 在に至る. 1982 年工学博士 (京都大学). 空気圧ア クチュエータ, 人間共存型ロボット, 機械システム の高機能化制御に関する研究に従事。(日本ロボット学会正会員)

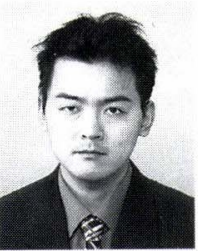

佐々木大輔（Daisuke Sasaki）

1977 年 1 月 28 日生. 2001 年岡山大学大学院自然 科学研究科博士前期課程修了. 同年岡山大学大学院 自然科学研究科博士後期課程入学. 空気圧ソフトメ カニズムを用いた人間共存型ロボットの開発に関す る研究に従事.

(日本ロボット学会学生会員)

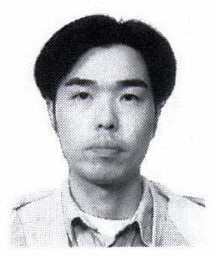

井上隆志 (Takashi Inoue)

1974 年 7 月 5 日生. 1997 年岡山大学工学部機械 工学科卒業. 1999 年岡山大学大学院工学研究科修 士課程修了。同年 (株) 島津製作所に入社，現在に 至る。 